\title{
Using yttrium as an indicator to estimate total rare earth element concentration: a case study of anthracite-associated clays from northeastern Pennsylvania
}

\author{
Xiaojing Yang1 ${ }^{1}$ Daniel Kozar ${ }^{1} \cdot$ Daniel Gorski ${ }^{2} \cdot$ Anthony Marchese $^{2} \cdot$ \\ James Pagnotti $^{3} \cdot$ Rusty Sutterlin $^{4} \cdot$ Mohammad Rezaee $^{1} \cdot$ Mark S. Klima $^{1}$ • \\ Sarma V. Pisupati ${ }^{1}[$
}

Received: 8 December 2019/Revised: 5 February 2020/Accepted: 27 March 2020/Published online: 17 April 2020

(C) The Author(s) 2020

\begin{abstract}
This study demonstrated using yttrium (Y) as an indicator to estimate the total rare earth element and $\mathrm{Y}$ contents (REY) in coal-associated samples and to facilitate selection of samples with high REY assays in a fast and inexpensive manner. More than 10 anthracite-associated samples were collected from each of three Pennsylvanian sites (sites B, J and C) based on Thorium gamma ray logging suggesting high REY content. Several samples from each site were analyzed by ICP-MS to determine the rare earth distribution patterns and to establish the site-specific linear equations of Y and REY. The Y contents of the remaining samples were measured by a portable X-ray fluorescence analyzer, and the REY values were estimated based on the site-specific linear equation developed earlier. R-squared values above 0.70 were obtained for all the estimation equations from all three sites on both a whole sample basis and an ash basis. Previously, ash content has been widely used as an indicator of high REY content. This may not be applicable for a specific site. Site B in this study is an example where ash contents could not be statistically correlated with REY, so using Y for estimation is more applicable. The demonstrated sample screening process is suitable for samples from sites that share more similar distribution patterns (either MREY or LREY or HREY) as well as for samples from sites that share multiple distribution patterns (LREY/ MREY/HREY) depending on the desirable accuracy. The demonstrated process lowers the analytical cost from $\$ 70$ to 80 dollars per sample to $\$ 10-15$ per sample while significantly reducing the processing time and acid consumption for ICP digestion. This is particularly true when a relatively large sample size is involved, for example, 100 samples from one site analyzed by ICP-MS/OES.
\end{abstract}

Keywords Rare earth elements $\cdot$ XRF analysis · Correlations $\cdot$ Prediction $\cdot$ ICP analysis

Sarma V. Pisupati

sxp17@psu.edu

$1 \quad$ John and Willie Leone Family Department of Energy and Mineral Engineering and the EMS Energy Institute, Center for Critical Minerals, The Pennsylvania State University, 110 Hosler Building, University Park, PA 16802, USA

2 Texas Mineral Resources Corporation, 539 El Paso St, Sierra Blanca, TX 79851, USA

3 Pagnotti Enterprises, 46 Public Square, Wilkes-Barre, PA 18701, USA

4 Inventure Renewables, Inc, 1616 25th Avenue, Tuscaloosa, AL 35401, USA

\section{Introduction}

The demand for rare earth elements (REEs) is increasing due to the development of advanced technologies. REEs have found numerous uses in high technology applications such as high-strength permanent magnets, lasers, automotive catalytic converters, superconductors, and electronic devices (Yanfei et al. 2015). REEs are one of the 35 critical minerals listed by the U.S. Department of Interior in 2018 (DOI 2018). Bastnaesite ( $\mathrm{La}, \mathrm{Ce}) \mathrm{FCO}_{3}$, monazite (Ce, $\mathrm{La}$, $\mathrm{Y}, \mathrm{Th}) \mathrm{PO}_{4}$, xenotime $\mathrm{YPO}_{4}$, and the weathered crust elution-deposited (ion-adsorbed type) ores are the main commercial sources of rare earth minerals. In order to expand the reserves of REEs globally, coal and coal by- 
products are being evaluated as potential economic sources of REEs. High levels $(>0.1 \%)$ of total REEs have been found in coal seams and coal ashes, as well as in the host and basement rocks of some coal basins. Coal fly ash contains on average $445 \mathrm{ppm}$ of REEs on a global basis (Seredin and Dai 2012; Franus et al. 2015). To further explore the potential opportunities for recovering REEs from coal-based resources, the US Department of Energy (DOE) initiated a Rare Earth Elements and Critical Minerals program. DOE suggested a $300 \mu \mathrm{g} / \mathrm{g}$ (ppm) level of REEs plus yttrium (REY) as a minimum level for potential REY resources on a whole sample basis (DOE 2014).

The concentrations of REY are commonly determined using inductively coupled plasma optical emission spectrometry (ICP-OES) and inductively coupled plasma mass spectrometry (ICP-MS). The sample preparation for ICPOES or -MS both require ashing and acid digestion prior to the analysis. In addition, turnaround times of 10 days are not uncommon in a commercial lab. As such using these methods to determine REYconcentrations among hundreds of samples would be expensive and time consuming.

Alternative techniques have been recently explored for determining REY content in coal fly ash. One such technique, the sensitive high-resolution ion microprobe-reverse geometry (SHRIMP-RG) analysis (Kolker et al. 2017), gave an analytical uncertainty of $\pm 10 \%-20 \%$ when used for determining REEs in fly ash aluminosilicate glasses. This method was able to reveal not only the concentrations, but also some mineral association information. However, this technique is not commonly available. For rapid detection and analysis of REEs, laser-induced breakdown spectroscopy (LIBS) has been applied for REE peak identifications in monazite sand and coal ash (Abedin et al. 2011; Phuoc et al. 2016). Bhatt et al. (2017) have used this method to quantitatively analyze REEs in geological samples. Lanthanum (La), cerium (Ce), and neodymium $(\mathrm{Nd})$ were found in all samples and were comparable to those obtained by ICP-MS analysis where the other REEs were partially detected. However, the samples analyzed contained over $8000 \mathrm{ppm} \mathrm{Ce}, \mathrm{La}$, and $\mathrm{Nd}$. Hence it remains unknown whether this method will be suitable to determine REY content in coal associated samples whose individual REEs are usually in the 10-100 ppm range. A method to estimate REY content rapidly using thorium (Th) gamma ray logging and a linear relationship between thorium content and total REEs was described (DOE 2017). Despite a possible broad general correlation between total REEs and Th, others have also reported that the total REEs of individual samples showed little correlation with that of Th (Wedow 1967; Staatz et al. 1972, 1974; Staatz 1983; Christman et al. 1959). Another possible problem with this correlation is that a representative measurement of $\mathrm{Th}$ for individual samples is difficult to obtain; the measured values could have a standard deviation as high as $7.5 \mathrm{ppm}$ at a low concentration level $(\mathrm{Th}<20 \mathrm{ppm})$ (Li et al. 2016).

$\mathrm{X}$-ray fluorescence (XRF) analysis has also been used to determine REE concentrations. It was first explored in the late 1960s, however the method described during that time was not extended to microgram concentration levels (Rose and Cuttitta 1968) and the samples needed to contain high REE concentrations (Aleksiev and Boyadjieva 1966). Eby (1972) used XRF analysis to determine REEs, yttrium (Y), and scandium (Sc) of some standard rocks from the US Geological Survey (USGS 2014). The results were compared with literature values and indicated a 10\%-30\% difference at the ppm level (Eby 1972). Uhrin (2018) proposed a correlation for identifying and quantifying REEs in coal-associated samplesusing a field-portable XRF analyzer. Although lanthanum (La), cerium $(\mathrm{Ce})$,praseodymium (Pr), and neodymium $(\mathrm{Nd})$ could be detected by the XRF analyzer, concentrations of these elements in coalassociated materials are often close to $10 \mathrm{ppm}$. At these levels, the concentration error would be too broad to allow standard compositions to be used as references, so $\mathrm{Y}$ was used as a tracer for total REEs (Uhrin 2018).

Although $\mathrm{Y}$ is not specifically an REE, it is grouped with REEs as the properties are close to other lanthanides. For example, the ionic radius of $\mathrm{Y}^{3+}$ is similar to holmium $(\mathrm{Ho})^{3+}$. It is considered to fall between dysprosium $(\mathrm{Dy})^{3+}$ and $(\mathrm{Ho})^{3+}$ in normalized REY distributions and is considered as a medium REE (Bau and Peter 1996; Seredin and Dai 2012; Dai et al. 2016). Due to this similarity in ionic radius, $\mathrm{Y}$ exhibits similar chemical properties and typically occurs in the same deposits as REEs (USGS 2014). The REY distributions as used in this study are classified into 3 types:light (LREY)—La, Ce, $\mathrm{Pr}, \mathrm{Nd}$, and samarium (Sm); medium (MREY)- Europium (Eu), gadolinium (Gd), terbium ( $\mathrm{Tb})$, Dy, and $\mathrm{Y}$; and heavy (HREY)—Ho, erbium (Er), thulium (Tm), ytterbium (Yb), and lutetium (Lu) (Blissett et al. 2014; Seredin and Dai 2012). A binary classification of REEs is also commonly used: LREE (La, Ce, Pr, Nd, Sm, and Eu) and HREE (Gd, $\mathrm{Tb}$, Dy, Y, Ho, Er, Tm, Yb, and Lu) (Wang and Liang 2015).

To determine the relative amounts of REY in each sample, a distribution pattern plot was developed. These distribution plots give REY concentrations in the samples normalized to a standard material. The current study adopted the Upper Continental Crust (UCC) as the standard material (Taylor and McLennan 1985). The UCC shares a similar genetic origin to coal as coal was deposited within the UCC. This approach was used by previous researchers that focused on coal-associated samples from various sources (Dai et al. 2014a, b, 2016). Three types of REY distributions were identified based on UCC normalizations 
(Seredin and Dai 2012; Dai et al. 2016): L-type (lightREY; $\mathrm{La}_{N} / \mathrm{Lu}_{\mathrm{N}}>1$ ); M-type (medium-REY; $\mathrm{La}_{\mathrm{N}} / \mathrm{Sm}_{\mathrm{N}}$ $<1, \mathrm{Gd}_{N} / \mathrm{Lu}_{\mathrm{N}}>1$ ); and H-type (heavy REY; $\mathrm{La}_{N} / \mathrm{Lu}_{\mathrm{N}}$ $<1)$. In cases where the original material was of magmatic origin, chondrite was used for normalization (Zhou et al. 2000; Dai et al. 2011, 2016). Other standards like the North American Shale Composite (NASC) and Post-Archaean Australian Shale (PAAS) have also been used depending on the sampling characteristics (Dai et al. 2016). For example, Noack et al. (2015) studied the REE distributions in eleven outcrop samples and six, depth-interval samples of a core from the Marcellus shale. These values were normalized by referencing the PAAS of Nance and Taylor (1976).

Previous work done by Uhrin (2018) provided an approach for using XRF analysis to provide a fast and inexpensive way to estimate REY concentrations in the field. The current study has refined the method to select or locate high REY assays from a specific coal seam or coalassociated material. The procedure required analyzing several samples from the original collected material using ICP-OES or ICP-MS to determine the REY concentrations and then developing a site-specific linear correlation with Y. Uhrin (2018) proposed a general Y-REY correlation where $Y$ was correlated with HREE, and REY was estimated using HREE $=0.1 \times$ REY. However, the correlation HREE $=0.1 \times$ REY may not be applicable for samples that share M-REY or H-REY distribution patterns. Thus, having a site-specific Y-REY correlation would take into consideration the distribution patterns from the sites and lead to a more accurate prediction. The $\mathrm{Y}$ values for the remaining samples were then obtained by XRF analysis, and the correlation was used to calculate REY concentration. With this approach, the number of required ICP analyses would be reduced, significantly reducing process time. Moreover, ashing and acid digestion are not required for XRF analysis. The current study also describes the current state of knowledge on anomalous REY concentrations within some Pennsylvania sites as most recent studies on coal-related REY have focused on coals from China, Far East Russia, and Kentucky in the U.S. (Dai et al. 2016).

\section{Materials and methods}

\subsection{Sample collection and preparation}

Samples were obtained from several locations within Pennsylvania. The samples consisted of sandstone, coal, and shale. Site B samples are chip channel rock samples collected by Jeddo Coal Co. from the Upper Lehigh No. 5 property. Hand samples were collected from another nearby Upper Lehigh site (Site J). A drill core sample was obtained from site $\mathrm{C}$ from the Jeddo Coal Co Eckley North property that covered a depth of 39.2 to $102.3 \mathrm{ft}$. Subsamples from Site B and Site $\mathbf{J}$ and each core sample were ground to pass through a $75 \mu \mathrm{m}$ screen. Representative samples of approximately $1 \mathrm{~g}$ and $5 \mathrm{~g}$ were used for ICP and XRF analyses, respectively.

\subsection{ICP-MS and ICP-OES analysis}

Six samples from Site B and Site J were analyzed by ICPMS (Thermo Fisher Scientific Xseries 2) at Penn State. These samples and ten samples from Site $\mathrm{C}$ were also analyzed by ICP-OES at a commercial lab. Both ICP-OES and ICP-MS allow a detection limit as low as 1 part per trillion (ppt) for REEs. Acid-digestion using the $\mathrm{HNO}_{3}$, $\mathrm{HCl}$, HF process was adopted for ICP-OES (ASTM D6357-11 2011). A lithium metaborate $\left(\mathrm{LiO}_{2}\right)$ fusion method adapted from Suhr and Ingamells (1966) was used for ICP-MS digestion: $0.100 \mathrm{~g}$ of each sample was placed in the mixture with $0.400 \mathrm{~g} \mathrm{LiO}_{2}$ flux, heated to $915^{\circ} \mathrm{C}$ in a graphite crucible, and the resultant bead was dissolved in a stirred $100 \mathrm{~mL}$ 5\% nitric acid solution. Samples were further diluted by ten times in $0.3 \mathrm{~N}$ nitric acid to reduce the matrix for ICP-MS analysis. Calibration curves were created using a serial dilution of a calibration standard, a custom multi-element calibration standard from High Purity Standards along with digested coal fly ash (NIST 1633 and NIST 1633a) and combinations of USGS rock standards (BHVO-1, BCR-1, BIR-1 RGM-1) and Japanese Geological Survey standard JA-1.

\subsection{XRF analysis}

A linear fit between total REEs and $\mathrm{Y}$ was generated for each site. XRF analysis was used to determine the $\mathrm{Y}$ values for the remaining collected samples using an XRF analyzer (Thermo Scientific Niton FXL FM). The REY concentrations were then calculated using the site-specific functions. The $\mathrm{Y}$ values provided by XRF analysis were validated with ICP-MS (Penn State). Because of the relatively fast turn around time for XRF analyses, it is possible to screen many samples and select the highest $\mathrm{Y}$ samples for more detailed ICP analysis. The ash content was determined as Ash $(\%)=100-$ LOI $(\%)$. The loss on ignition (LOI, in percent) was determined by ashing the sample at a $900{ }^{\circ} \mathrm{C}$ overnight.

\section{Results}

All the samples from site $\mathrm{J}$ in Fig. 1 satisfied $\mathrm{La}_{\mathrm{N}} / \mathrm{Sm}_{\mathrm{N}}$ $<1, \mathrm{Gd}_{\mathrm{N}} / \mathrm{Lu}_{\mathrm{N}}>1$, meaning they were all M-type REEs as discussed previously. Samples J1 and J4 had small Eu 


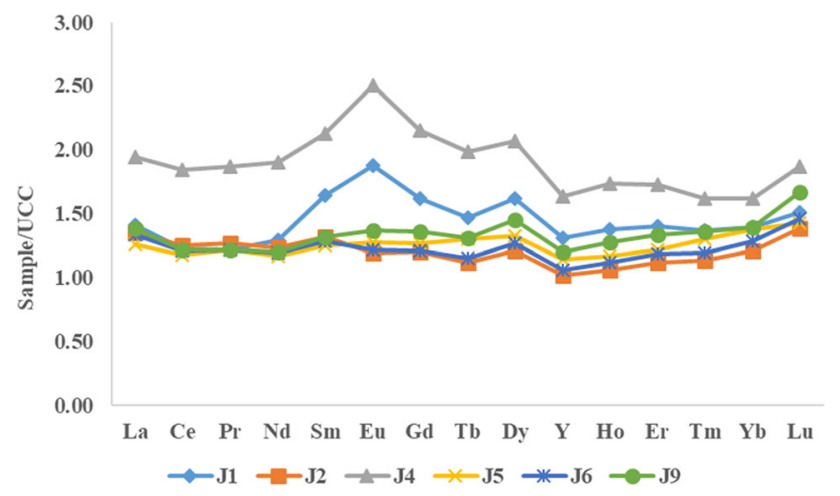

Fig. 1 REY distribution patterns for samples J1, J2, J4, J5, J6, and J9 from Site J

anomalies at 1.15 and 1.17 while having an Eu maximum and the rest shared a Dy maximum. Here Eu anomalies were calculated as $\mathrm{Eu}_{\mathrm{N}} / \mathrm{Eu}_{\mathrm{N}}^{*}=\mathrm{Eu}_{\mathrm{N}} /\left(0.5 \mathrm{Sm}_{\mathrm{N}}+0.5 \mathrm{Gd}_{\mathrm{N}}\right)$. (Dai et al. 2016). These distributions were similar to those reported for roof strata of the No. 25 coal from the Guxu Coalfield in China (Dai et al. 2016) (Fig. 2).

The REY values for samples J1, J2, J4, J5, J6, and J9 were obtained on a whole sample basis and on an ash basis and were fitted to linear curves (Fig. 3a) as described in the method section. At site $\mathrm{J}$, the ash content of all analyzed samples was also plotted against REY concentration (Fig. 3b). In this case, ash content was highly associated $\left(R^{2}=0.99\right)$ with REY (grey).

Samples B1-B7 were analyzed by ICP-MS to determine the individual REY. All samples from Site B (Fig. 4) also followed the $\mathrm{La}_{N} / \mathrm{Sm}_{\mathrm{N}}<1, \mathrm{Gd}_{N} / \mathrm{Lu}_{\mathrm{N}}>1$ trend, indicating M-type REEs as was found for Site J. Positive Eu anomalies were observed for most samples ranging from 1.1 to 1.6 except for $\mathrm{B} 2$ and $\mathrm{B} 3$ for which $\mathrm{Eu}_{\mathrm{N}} / \mathrm{Eu}_{\mathrm{N}}^{*}=1$. A Sm maximum was observed for samples B2 and B3 (Fig. 4). The enrichment level in samples from Site B were similar to those from Site J. No obvious negative anomalies were observed (Figs. 2 and 4).

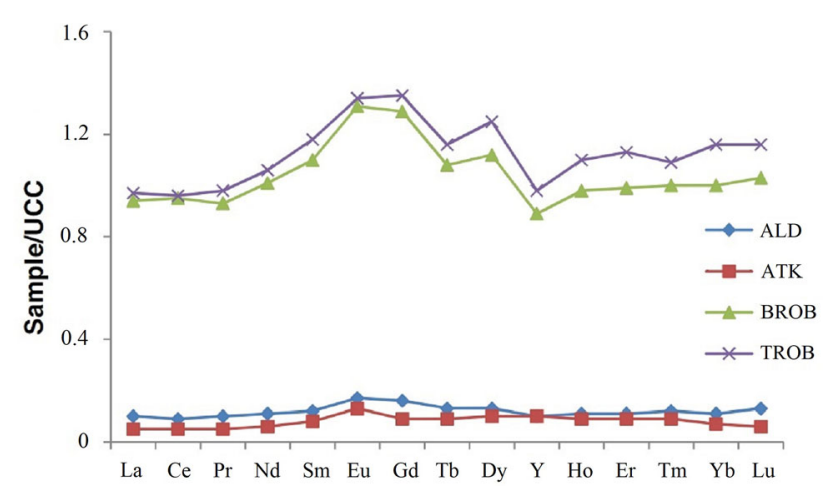

Fig. 2 Roof strata of the No. 25 coal from the Guxu coalfield, data from Dai et al. (2015), figure from Dai et al. (2016)
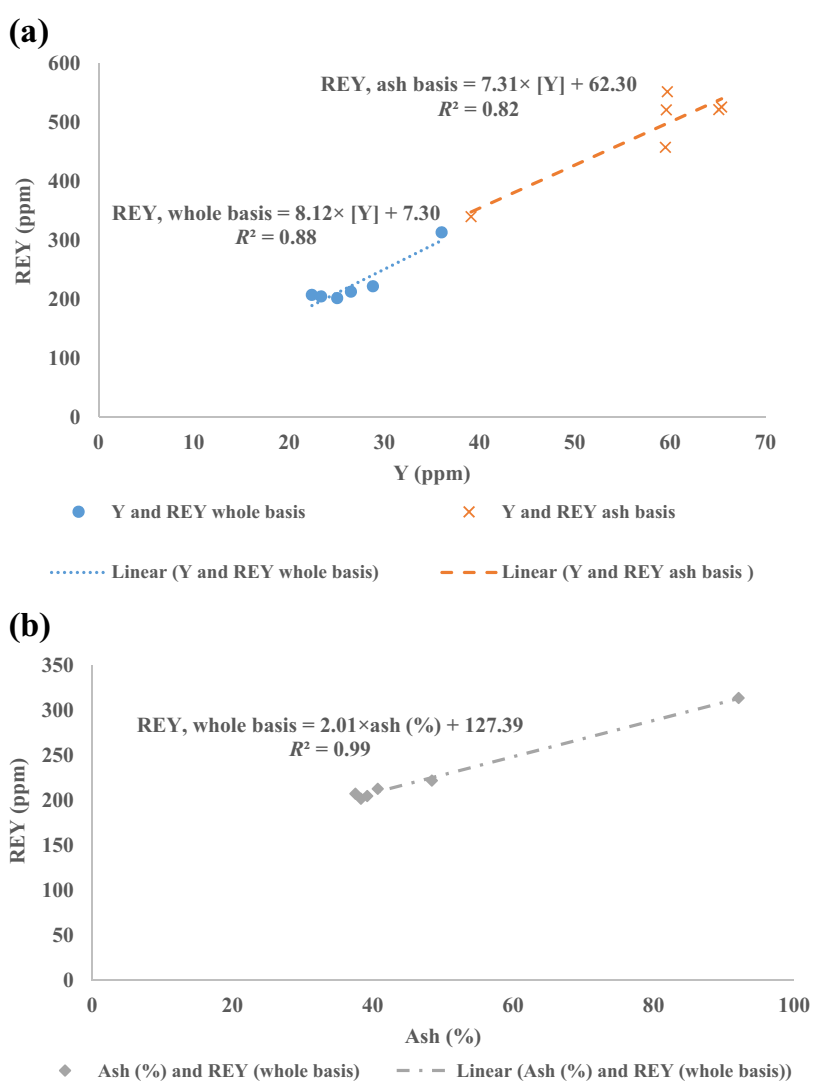

Fig. 3 a Linear correlations of Y versus REY for samples collected from Site J. b Linear correlations of ash content versus REY for samples collected from Site $\mathbf{J}$

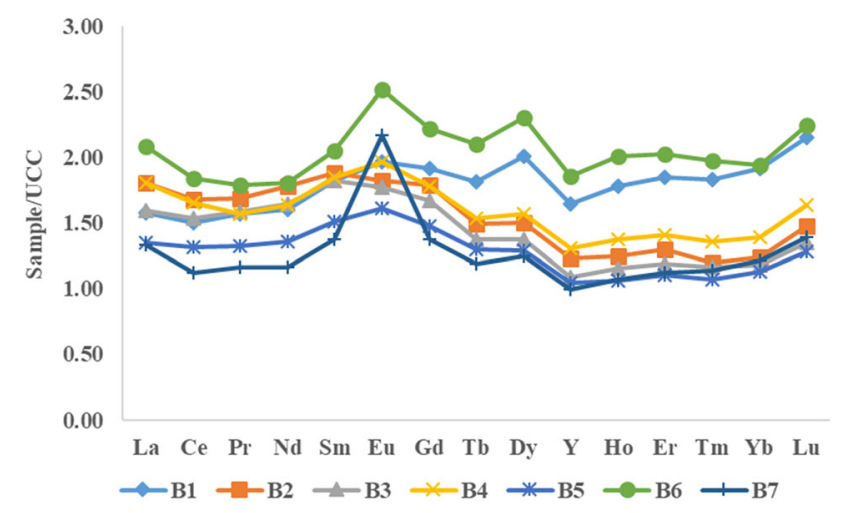

Fig. 4 REY distribution patterns for samples B1-B7 from Site B

No correlation between the ash content and REY content was found for samples from Site B (Fig. 5). On the other hand, the REY versus Y linear fit (on an ash basis) was significantly better $\left(R^{2}=0.96\right)$ than that on the whole basis $\left(R^{2}=0.77\right)$ (Fig. 6).

$\mathrm{Y}$ values for samples B1-B7 from site B were measured by ICP and XRF. ICP-OES was done at a commercial lab following a microwave acid digestion process, while ICPMS was done at Penn State using the $\mathrm{LiO}_{2}$ fusion method 


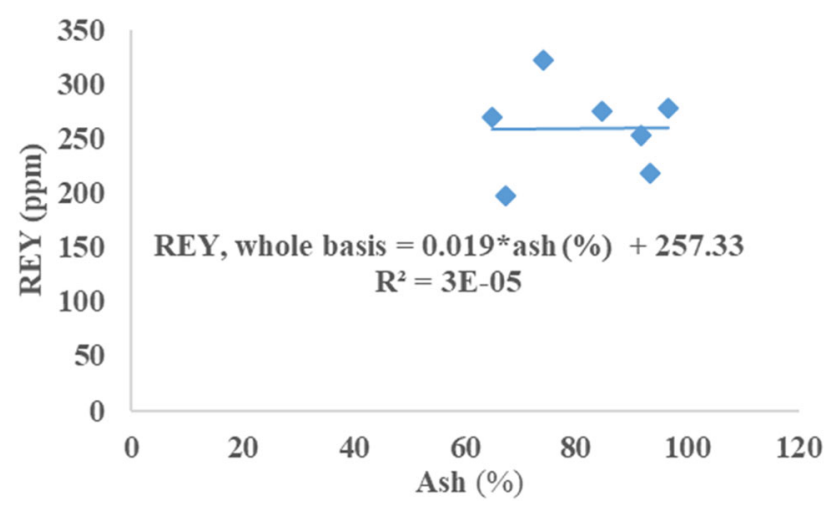

Fig. 5 Variation of REY (whole basis) with ash content for Site B samples

(Fig. 7). All three values were comparable with the highest difference being 7 ppm (Fig. 7, Sample B1).

After the linear correlation was developed from samples B1-B7, the Y values for samples B8-B11 were measured using the XRF analyzer. The REY values were calculated by REY (whole basis, ppm) $=5.11 \times[\mathrm{Y}]+128.01$. The error bars for samples B1-B7 were negligible, since the measured values would be used to compare to the calculated values of samples B8-B11. These results are shown in Fig. 8. Here, sample B6 had the highest REY and was chosen for future experiments.

Due to the similarities of samples from site B and site $\mathbf{J}$ in terms of REY distributions and the level of enhancement, Y values obtained by XRF analysis were used to calculate the REY values for the site $\mathrm{J}$ samples using the equation generated from site $B$ samples $(\mathrm{REY}=8.12 \times[\mathrm{Y}]+7.30)$ and the equation generated from Site $\mathrm{J}$ samples $(\mathrm{REY}=5.11 \times[\mathrm{Y}]+128.01)$ (Figs. 3 and 9). The $\mathrm{Y}$ values for samples $\mathrm{J} 3$ and $\mathrm{J} 8$ were determined by XRF analysis and were added to the figure for

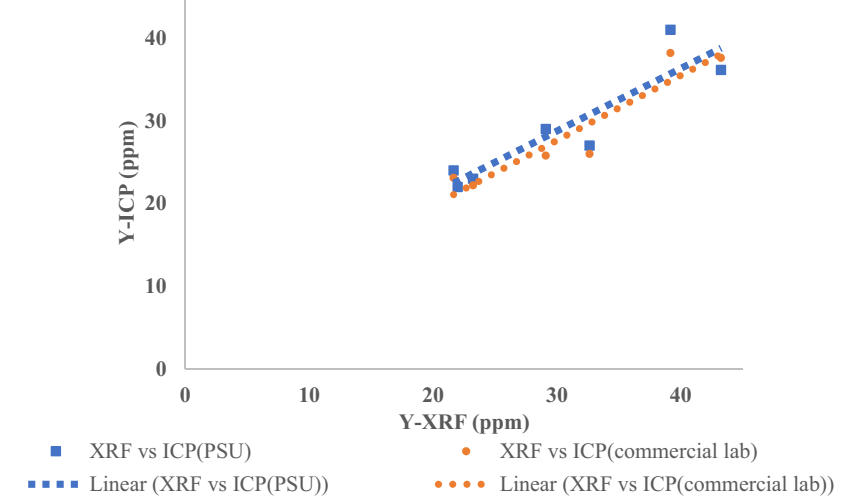

Fig. 7 Comparison of $\mathrm{Y}$ values obtained using ICP and XRF techniques for samples (B1-B7) collected from Site B

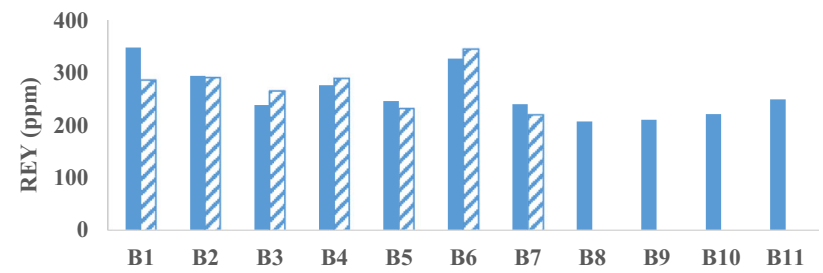

a calculated REY from Figure 6 (whole basis) $\square$ measured REY (ICP PSU, whole basis)

Fig. 8 The calculated REY values for samples B7-B11 from Site B

comparison. Most calculated values were similar except for sample J8. Sample J4 had the largest difference when comparing the calculated values to the measured ones. However, during sample selection, the measured data would also be compared to the calculated data for the rest of the samples. Here, samples J3 and J4 were selected for future studies.

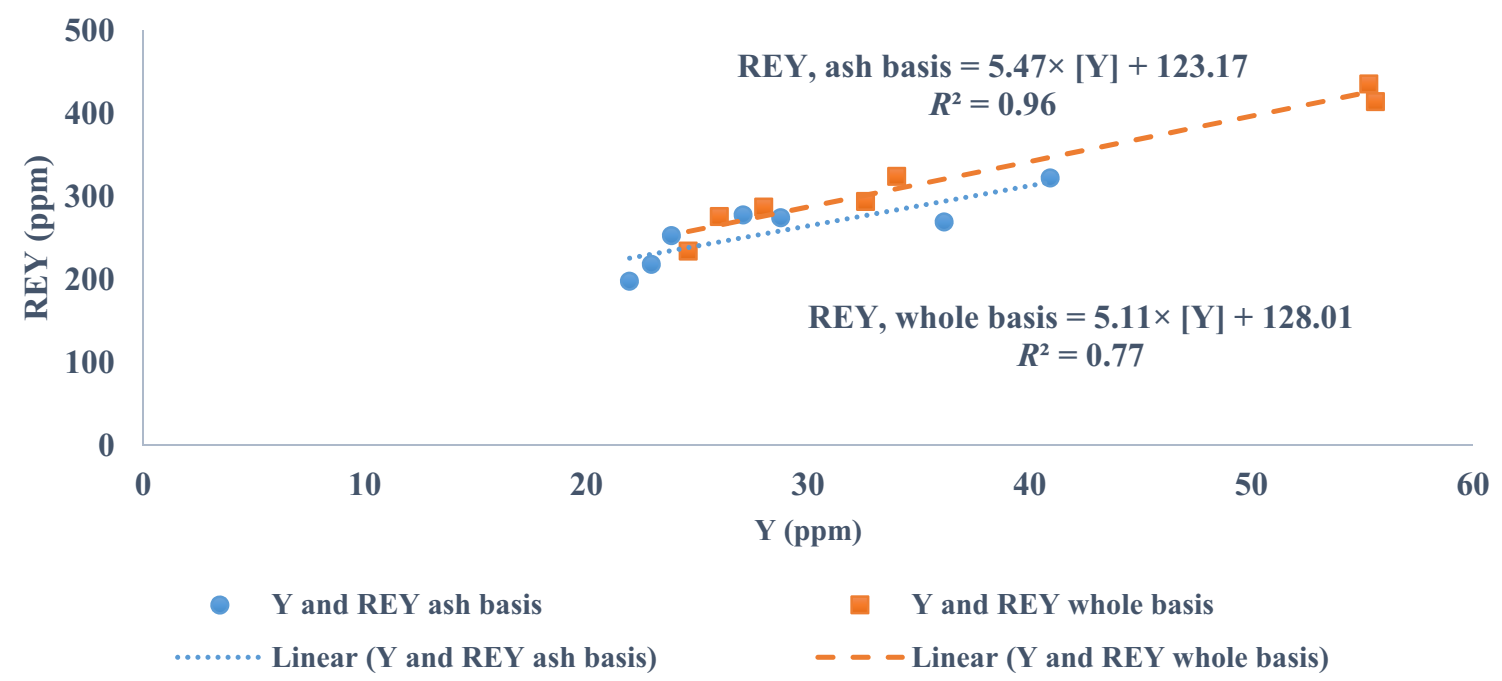

Fig. 6 Linear correlations of REY versus Y for samples collected from Site B 


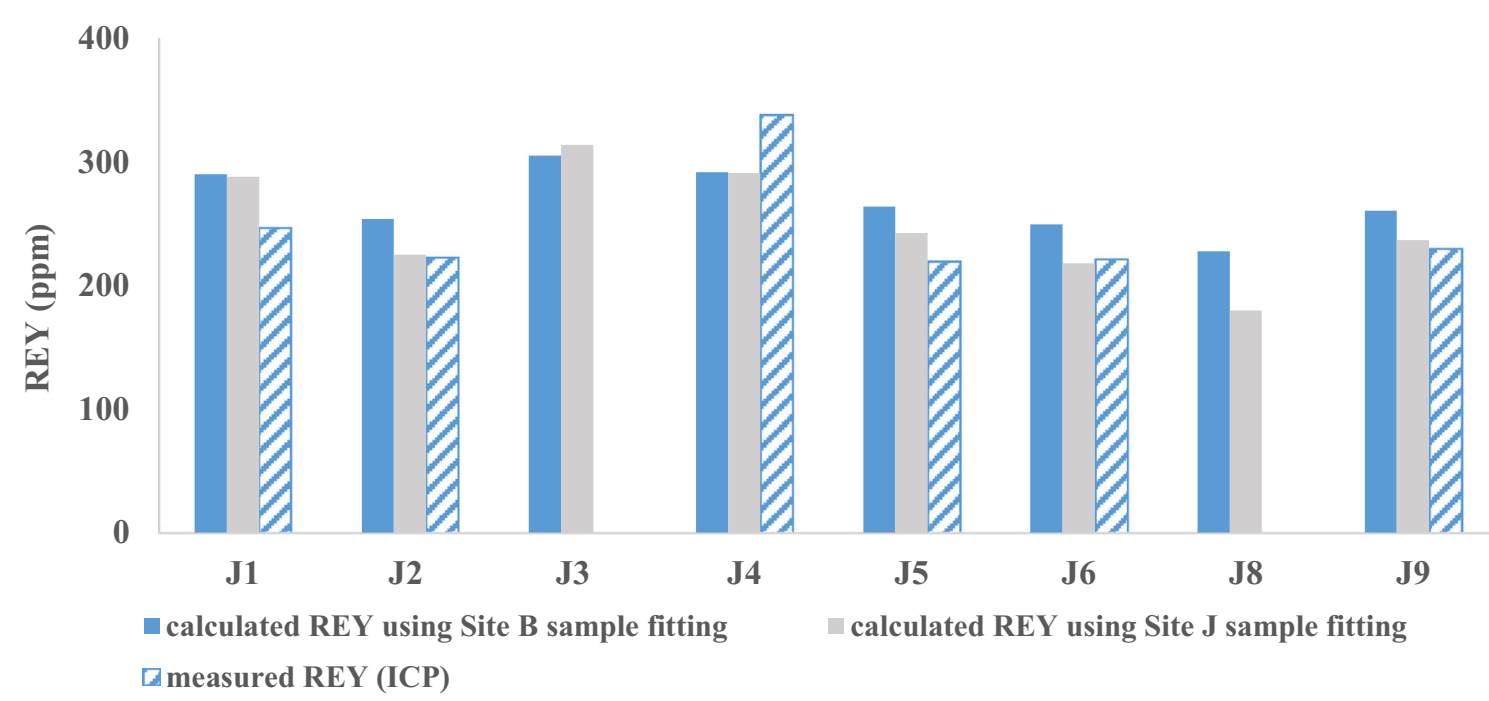

Fig. 9 The calculated and measured REY values of samples from Site $\mathbf{J}$

As indicated previously, Site C samples were collected from a drilled core and were separated based on the depth of mining. The depth and thickness of each core sample is listed in Table 1. Subsamples (Table 2) were selected based on the Th gamma ray logging data collected

Table 1 Samples collected from Site $\mathrm{C}$ and their corresponding depths

\begin{tabular}{lclc}
\hline Core number & Depth $(\mathrm{ft})$ & Core number & Depth $(\mathrm{ft})$ \\
\hline 1 & $39.2-39.7$ & 22 & $79.0-79.2$ \\
2 & $42.7-42.9$ & 23 & $79.2-80.2$ \\
3 & $48.2-48.8$ & 24 & $80.6-81.2$ \\
4 & $50.3-50.6$ & 25 & $81.6-83.6$ \\
5 & $51.3-51.6$ & 26 & $83.6-83.8$ \\
6 & $56.5-59.3$ & 27 & $83.8-85.1$ \\
7 & $59.3-59.5$ & 28 & $85.1-87.0$ \\
8 & $59.5-61.1$ & 29 & $87.0-88.4$ \\
9 & $61.1-62.1$ & 30 & $88.4-89.5$ \\
10 & $62.1-62.3$ & 31 & $89.5-89.8$ \\
11 & $62.3-62.9$ & 32 & $89.8-90.1$ \\
12 & $62.9-63.8$ & 33 & $90.1-91.9$ \\
13 & $63.8-64.0$ & 34 & $91.9-93.7$ \\
14 & $64.0-65.0$ & 35 & $93.7-95.2$ \\
15 & $65.0-66.5$ & 36 & $95.2-95.5$ \\
16 & $66.5-68.6$ & 37 & $95.5-96.2$ \\
17 & $68.6-70.8$ & 38 & $96.2-97.0$ \\
18 & $70.8-72.8$ & 39 & $97.0-98.8$ \\
19 & $72.8-74.6$ & 40 & $98.8-100.3$ \\
20 & $74.6-76.5$ & 41 & $100.3-102.3$ \\
21 & $76.5-78.3$ & & \\
\hline
\end{tabular}

Table 2 Site C samples selected for ICP analyses and their corresponding depths

\begin{tabular}{lcll}
\hline Core number & Depth $(\mathrm{ft})$ & $\mathrm{Y}(\mathrm{ppm})$ & REY $(\mathrm{ppm})$ \\
\hline 6 & $56.5-59.3$ & 41.7 & 299.2 \\
11 & $62.3-62.9$ & 46.9 & 324.2 \\
12 & $62.9-63.8$ & 48.0 & 359.9 \\
13 & $63.8-64.0$ & 47.4 & 362.0 \\
24 & $80.6-81.2$ & 37.8 & 300.7 \\
30 & $88.4-89.5$ & 23.8 & 180.7 \\
31 & $89.5-89.8$ & 27.7 & 290.5 \\
33 & $90.1-91.2$ & 28.9 & 285.1 \\
36 & $95.2-95.5$ & 41.1 & 289.8 \\
41 & $100.3-102.3$ & 53.7 & 350.2 \\
\hline
\end{tabular}

previously and were sent for ICP-OES analysis at a commercial lab.

There was no clear correlation between the enhancement of REY and the depth of drilling. Moreover, the distribution patterns could vary drastically between adjacent samples, for example, samples 30-31 (88.4-89.8 ft) (Table 2). The REY distributions of the samples were mostly M-type $\left(\mathrm{La}_{N} / \mathrm{Sm}_{\mathrm{N}}<1, \mathrm{Gd}_{\mathrm{N}} / \mathrm{Lu}_{\mathrm{N}}>1\right)$ except for cores 11, 24 and 33 (Fig. 10). Core 11 had an H-type distribution $\left(\mathrm{Gd}_{11} / \mathrm{Lu}_{11}<1, \mathrm{La}_{11} / \mathrm{Lu}_{11}<1\right)$ with a slight Dy maximum with no obvious anomalies. There were also slightly higher MREE and HREE enrichments compared to that of the LREE. Core 24 also had an H-type distribution $\left(\mathrm{Gd}_{24} / \mathrm{Lu}_{24}<1, \quad \mathrm{La}_{24} / \mathrm{Lu}_{24}<1\right)$ but with a small $\mathrm{Eu}$ anomaly $\left(\mathrm{Eu}_{\mathrm{N}} / \mathrm{Eu}_{\mathrm{N}}^{*} \cdot=1.26\right)$. Even though the $\mathrm{Yb}$ and $\mathrm{Lu}$ enhancements were slightly high making them H-type, the distribution pattern of core 24 showed some resemblance to 


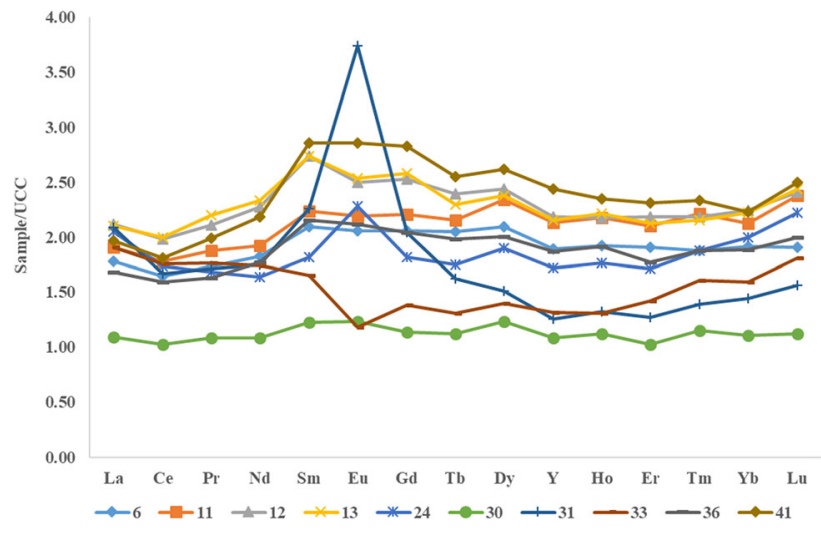

Fig. 10 REY distribution patterns for selected samples from Site C

that of samples obtained from Site B. Core 33 had the only L-type distribution $\left(\mathrm{La}_{33} / \mathrm{Lu}_{33}>1, \mathrm{La}_{33} / \mathrm{Sm}_{33}>1, \mathrm{Gd}_{33} /\right.$ $\left.\mathrm{Lu}_{33}<1\right)$ among the analyzed samples. It also had a lower enhancement of MREEs and a negative $\mathrm{Eu}$ anomaly $\left(\mathrm{Eu}_{\mathrm{N}} / \mathrm{Eu}_{\mathrm{N}}^{*}=0.78\right)$. None of these three samples had the highest REY and none of them contained any strongly pronounced anomalies (Table 2, Fig. 10).

Y did not display any obvious anomaly except core 31 . A linear relationship between REY and $\mathrm{Y}$ was obtained (Fig. 11). Core 31 had negative $Y$ anomalies $\left(\mathrm{Y}_{\mathrm{N}} / \mathrm{Y}_{\mathrm{N}}^{*}=0.88\right)$ with the most pronounced positive anomalies among all $\left(\mathrm{Eu}_{\mathrm{N}} / \mathrm{Eu}_{\mathrm{N}}^{*}=1.74\right)$ (Fig. 10).

The fitting curves obtained from site $\mathrm{C}$ were similar to the one obtained from Site B (whole basis) for $\mathrm{Y}$ values below 40 ppm (Fig. 11). Site B did not contain some of the high Y samples like Site C, and the use of the site B fitted curve would underestimate the high assays from site $\mathrm{C}$ if applied. XRF analysis was used to determine the $\mathrm{Y}$ values for the remaining core samples from Site C (Fig. 12). Although there were still no clear correlations between $\mathrm{Y}$ and the sampling depth, the samples with relatively higher $\mathrm{Y}$ values $(>40 \mathrm{ppm})$ were mostly observed around samples 6-13 (56.5-64.0 ft) and 32-41 (89.8-102.3 ft) (Tables 1 and 2, Fig. 12). Samples collected from the surface did not show high $\mathrm{Y}$ values (Fig. 12). The REY values were calculated respectively, and samples with a $300 \mathrm{ppm}$ or above REY values were selected for further analysis (Fig. 13).

\section{Discussion}

Site specific linear relationships giving REY concentration as a function of $\mathrm{Y}$ concentration were developed for coalrelated materials from three sites within Pennsylvania. The $R^{2}$ values were greater than 0.71 in all cases regardless of the basis of calculation. The fit was relatively good considering the differences among Site $\mathrm{C}$ samples. Although the locations of Site B and Site J were different, similar distribution patterns and concentrations were observed, and their estimation equations were interchangeable as shown in Fig. 9. The samples analyzed in this study had mostly M-type distributions with 1.5-2.0 times enhancement compared to the UCC. At any given site or coal seam, it is

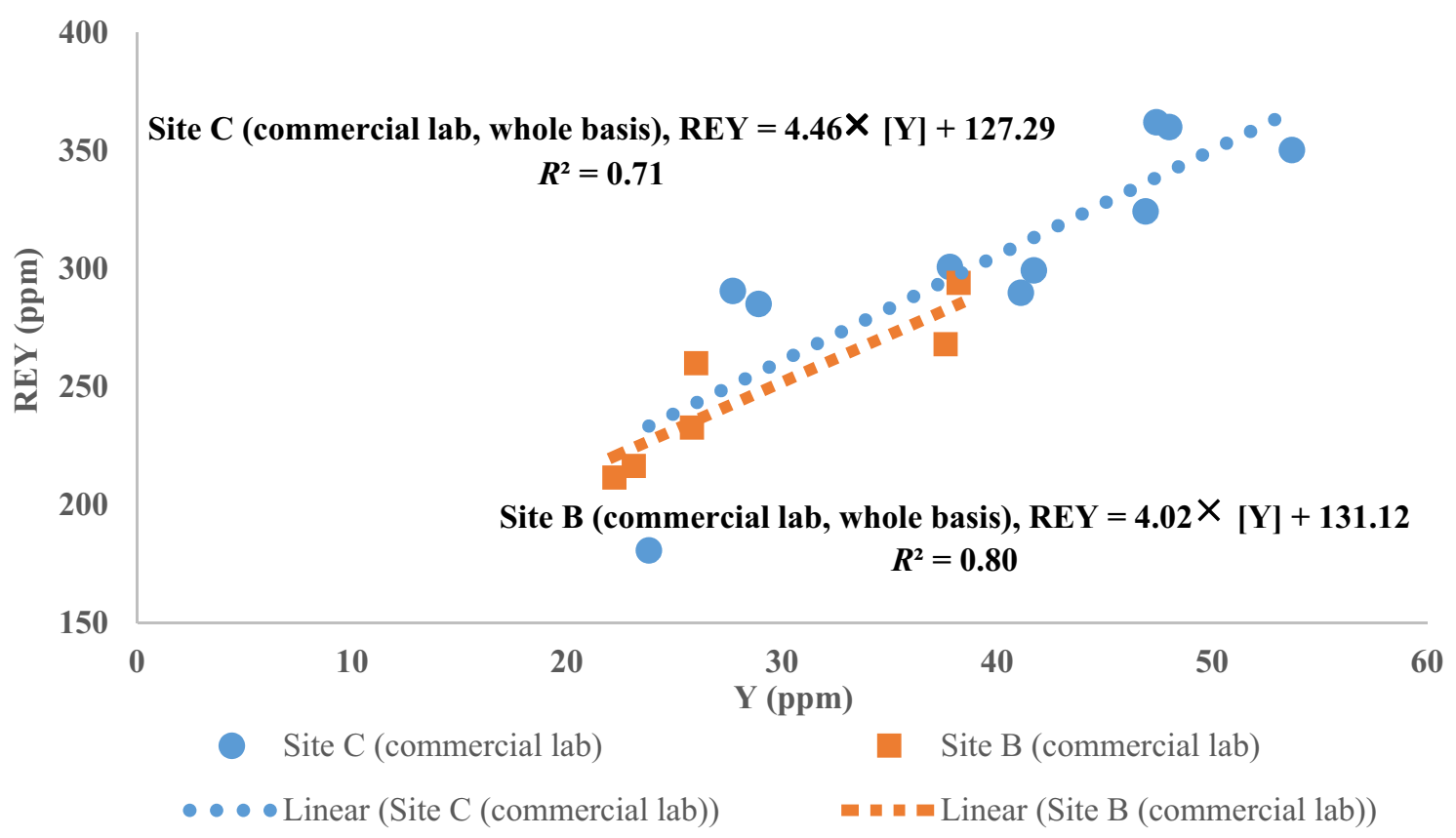

Fig. 11 Linear correlations of REY versus Y (whole basis) for samples collected from Site C. The linear correlation of REY versus Y for Site B was added for comparison 


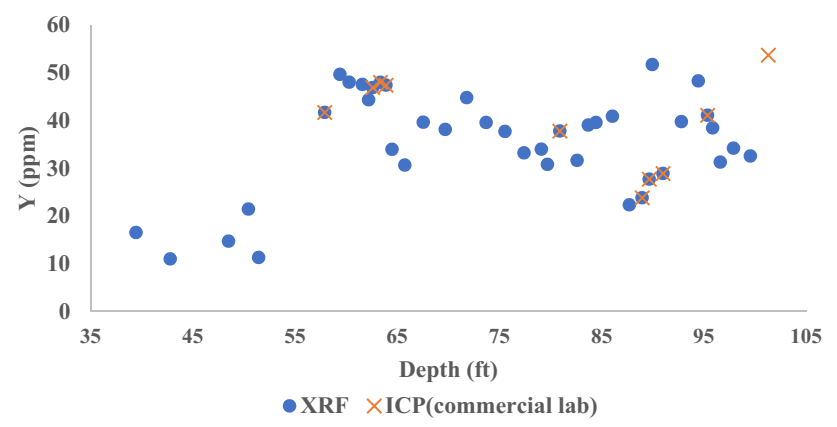

Fig. 12 Measured Y values for Site C

possible that a drastic difference in distribution patterns and REY can occur within a layer as narrow as three feet, thus additional samples from the area vary in concentrations of both individual REEs and total REY.

Previous research showed that standard ash values can also be directly correlated to REY concentration or aluminum on a broad basis, but the scattering of the data made it difficult to develop an appropriate estimation equation (Bryan et al. 2015). Similar to the Th relationship discussed previously, this correlation was developed on a large sample size scale, for example, all CoalQual Coal Samples (Bryan et al. 2015). However, each individual sampling site could exhibit totally different ash-REY relationships such as found for Site B and Site J. For example, in some cases a better estimate of REY concentration could be obtained using the ash content information compared to the REY-Y estimation method as shown for Site J. However, in other cases, such as when the ash content information is not available or when the ash content showed no correlation to
REY, using $\mathrm{Y}$ as an indicator to calculate REY from a specific site is advised. Obtaining the site-specific REY distribution patterns by ICP with fewer samples can provide not only the enhancement of individual REEs of the tested samples compared to the UCC, but also the homogeneity of the sampling site. Particularly when the samples display very different distribution patterns or if the $R^{2}$ value is too small, this method may not be suitable. The REY estimates indicated in this study were used to select the highest REY assays on a whole basis. However, if selecting the highest assays on an ash basis was the goal, the estimation could be based on equations generated on an ash basis by performing ash analyses on the remaining samples. The sampling sizes throughout this study were relatively small, which also contributed to the estimation error. The number of samples chosen for ICP analysis should be large enough to represent the entire set of samples. This screening method not only reduces the acid consumption and time for digestion significantly but is also more economical. To be specific, the cost of XRF analysis used in this study was $10 \%$ the cost for ICP-MS per sample. The overall analytical cost for the screening process during this study was only $15 \%-20 \%$ of that when the traditional ICP technique was used for all samples.

\section{Conclusions}

In this paper, correlations were developed using yttrium (Y) as an indicator to estimate the total rare earth element and Y contents (REY) in coal-associated samples, which

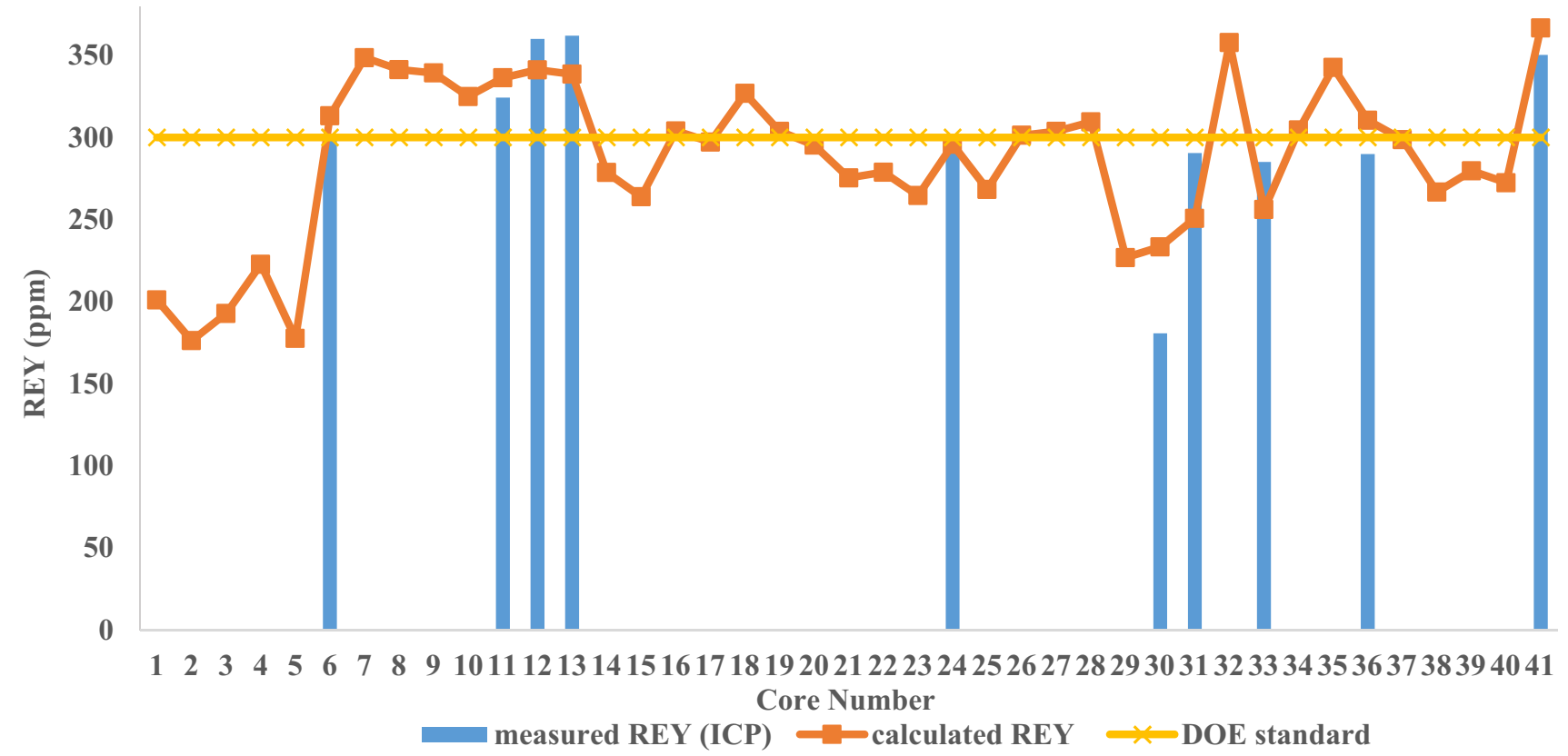

Fig. 13 REY values of the samples from Site C (samples with REY assays above the "selected" line were selected for further analysis) 
were obtained from three Pennsylvania sites. The correlations had $R$-squared values above 0.70 for all the estimation equations from all three sites on both a whole sample basis and an ash basis. Such correlations would aid in the technoeconomic feasibility of the process by facilitating selection of feedstocks with high REY assays. In addition, compared to using the traditional ICP measurements for all samples, using XRF as a screening process for the majority of the samples significantly reduced the acid consumption, time, and cost required during the ICP analysis, resulting in a faster and less expensive selection process.

Acknowledgements This study was supported by the Department of Energy [Grant Number DE-FE-0030146]. The authors thank Matthew Gonzales at Penn State University for the ICP-MS analysis.

Open Access This article is licensed under a Creative Commons Attribution 4.0 International License, which permits use, sharing, adaptation, distribution and reproduction in any medium or format, as long as you give appropriate credit to the original author(s) and the source, provide a link to the Creative Commons licence, and indicate if changes were made. The images or other third party material in this article are included in the article's Creative Commons licence, unless indicated otherwise in a credit line to the material. If material is not included in the article's Creative Commons licence and your intended use is not permitted by statutory regulation or exceeds the permitted use, you will need to obtain permission directly from the copyright holder. To view a copy of this licence, visit http://creativecommons. org/licenses/by/4.0/.

\section{References}

Abedin KM, Haider AFMY, Rony MA, Khan ZH (2011) Identification of multiple rare earths and associated elements in raw monazite sands by laser-induced breakdown spectroscopy. Opt Laser Technol 43(1):45-49

Aleksiev E, Boyadjieva R (1966) Content of rare earths in the standard igneous rocks, G-1, W-1 and G-B. Geochim et Cosmochim Acta 30:511-513

ASTM D6357-11 (2011) Test methods for determination of trace elements in coal, coke, \& combustion residues from coal utilization processes by inductively coupled plasma atomic emission, inductively coupled plasma mass, \& graphite furnace atomic absorption spectrometry. ASTM International, West Conshohocken, PA, www.astm.org

Bau M, Peter D (1996) Distribution of yttrium and rare-earth elements in the Penge and Kuruman iron-formations, transvaal supergroup, South Africa. Precambrian Res 79(1):37-55. https://doi. org/10.1016/0301-9268(95)00087-9

Bhatt CR, Jain JC, Goueguel CL, McIntyre DL, Singh JP (2017) Measurement of $\mathrm{Eu}$ and $\mathrm{Yb}$ in aqueous solutions by underwater laser induced breakdown spectroscopy. Spectrochim Acta - Part B Atom Spectrosc 137:8-12

Blissett RS, Smalley N, Rowson NA (2014) An investigation into six coal fly ashes from the United Kingdom and Poland to evaluate rare earth element content. Fuel 119:236-239. https://doi.org/10. 1016/j.fuel.2013.11.053

Bryan RC, Richers D, Andersen HT, Gary T (2015) Assessment of rare earth elemental contents in selected United States coal basins," Leonardo Technologies Inc. Document No: 114-910178X-100-REP-R001-00
Christman RA, Brock MR, Pearson RC, Singewald QD (1959) Geology and thorium deposits of the Wet mountains, Colorado: a progress report. US Geological Survey Bulletin 1072-H, H491-H535

Dai SF, Wang XB, Zhou YP, Hower JC, Li DH, Chen WM, Zhu XW, Zuo JH (2011) Chemical and mineralogical compositions of silicic, mafic, and alkali tonsteins in the late Permian coals from the Songzaocoalfield, Chongqing, southwest China. Chem Geol 282:29-44

Dai SF, Li T, Seredin VV, Ward CR, Hower JC, Zhou YP, Zhang MQ, Song XL, Song WJ, Zhao CL (2014a) Origin of minerals and elements in the Late Permian coals, tonsteins, and host rocks of the Xinde mine, Xuanwei, eastern Yunnan, China. Int J Coal Geol 121:53-78

Dai SF, Luo YB, Seredin VV, Ward CR, Hower JC, Zhao L, Liu SD, Zhao CL, Tian HM, Zou JH (2014b) Revisiting the late Permian coal from the Huayingshan, Sichuan, southwestern China: enrichment and occurrence modes of minerals and trace elements. Int J Coal Geol 122:110-128

Dai SF, Yang JY, Ward CR, Hower JC, Liu HD, Garrison TM, French D, O'Keefe JMK (2015) Geochemical and mineralogical evidence for a coal-hosted uranium deposit in the Yili Basin, Xinjiang, Northwestern China. Ore Geol Rev 70:1-30. https:// doi.org/10.1016/j.oregeorev.2015.03.010

Dai SF, Graham IT, Ward CR (2016) A review of anomalous rare earth elements and yttrium in coal. Int J Coal Geol 159:82-95. https://doi.org/10.1016/j.coal.2016.04.005

DOE (2014) Feasibility of recovering rare earth elements. US Department of Energy. Accessed on Jan 15th, 2019. https:// www.netl.doe.gov/coal/rare-earth-elements

DOE (2017) "Report on rare earth from coal and coal byproducts. report to Congress," January, EXEC-2014-000442,U.S. Department of Energy, Accessed on Jan 15 ${ }^{\text {th }}, 2019$. https://www. energy.gov/sites/prod/files/2018/01/f47/EXEC-2014-000442\% 20-\%20for\%20Conrad\%20Regis\%202.2.17.pdf

DOI (2018) Final list of critical minerals. 83FR23295, U.S Department of Interior. Accessed on Jan 15th, 2019. https://www. federalregister.gov/documents/2018/05/18/2018-10667/final-listof-critical-minerals-2018

Eby GN (1972) Determination of rare earth, yttrium, and scandium abundances in rocks and minerals by an ion exchange X-ray fluorescence procedure. Anal Chem 44(13):2137-2143

Franus W, Wiatros-Motyka M, Wdowin M (2015) Coal fly ash as a resource for rare earth elements. Environ Sci Pollut Res 22(12):9464-9474. https://doi.org/10.1007/s11356-015-4111-9

Kolker A, Scott C, Hower JC, Vazquez JA, Lopano CL, Dai S (2017) Distribution of rare earth elements in coal combustion fly ash, determined by SHRIMP-RG ion microprobe. Int $\mathrm{J}$ Coal Geol 184:1-10

Li BC, Wang NP, Wan JH, Xiong SQ, Liu HT, Li SJ, Zhao R (2016) In-situ gamma-ray survey of rare earth tailing dams: a case study in Baotou and Bayan Obo Districts, China. J Environ Radioact 151(1):304-310

Nance WB, Taylor SR (1976) Rare earth element patterns and crustal evolution-I. Australian post-Archean sedimentary rocks. Geochim et Cosmochim Acta 40(12):1539-1551. https://doi.org/10. 1016/0016-7037(76)90093-4

Noack CW, Jain JC, Stegmeier J, Hakala JA, Karamalidis AK (2015) Rare earth element geochemistry of outcrop and core samples from the Marcellus shale. Geochem Trans 16:6. https://doi.org/ 10.1186/s12932-015-0022-4

Phuoc TX, Wang P, McIntyre D (2016) Detection of rare earth elements in Powder River basin sub-bituminous coal ash using laser-induced breakdown spectroscopy (LIBS). Fuel 163:129-132 
Rose HJ Jr, Cuttitta F (1968) X-ray fluorescence analysis of individual rare earths in complex minerals. Appl Spectrosc 22(5):426-430. https://doi.org/10.1366/0003702687743384687

Seredin VV, Dai S (2012) Coal deposits as potential alternative sources for lanthanides and yttrium. Int J Coal Geol 94:67-93. https://doi.org/10.1016/j.coal.2011.11.001

Staatz MH (1983) Geology and description of thorium and rare-earth deposits in the southern Bear Lodge mountains, northeastern Wyoming. U.S Geological Survey Professional Paper 1049-D. U.S Government Printing Office, Washington. https://pubs.usgs. gov/pp/1049d/report.pdf

Staatz MH, Shaw VE, Wahlberg JS (1972) Occurrence and distribution of rare earths in the Lemhi Pass thorium veins, Idaho and Montana. Econ Geol 67(1):72-82

Staatz MH, Shaw VE, Wahlberg JS (1974) Distribution and occurrence of rare earths in the thorium veins on Hall mountain, Idaho. US Geol Surv J Res 2(6):677-683

Suhr NH, Ingamells CO (1966) Solution technique for the analysis of silicates. Anal Chem 38(6):730-734. https://doi.org/10.1021/ ac60238a015

Taylor SR, McLennan SH (1985) The continental crust: its composition and evolution. Blackwell, Oxford, pp 1-312

Uhrin R (2018) REE identification and characterization of coal and coal by-products containing high rare earth elements concentrations. Accessed on Dec 18th 2018. https://www.netl. doe.gov/sites/default/files/netl-file/2018_Poster-13_FE0026527_ Xlight.pdf

USGS (2014) The rare-earth element—vital to modern technologies and lifestyles. US Geological Survey, https://pubs.usgs.gov/fs/ 2014/3078/pdf/fs2014-3078.pdf. Accessed on Jan $15^{\text {th }} 2019$

Wang LQ, Liang T (2015) Geochemical fractions of rare earth elements in soil around a mine tailing in Baotou, China. Sci Rep 5(12483):1-11. https://doi.org/10.1038/srep12483

Wedow H (1967) The Morror do Ferro thorium and rare-Earth ore deposit, Pocos de Caldas district, Brazil, Uranium Investigations in Brazil. Geological survey bulletin 1185-D, United States Government Printing Office, Washington. https://pubs.usgs.gov/ bul/1185d/report.pdf

Xiao YF, Feng ZY, Huang XW, Huang L, Chen YY, Wang LS, Long ZQ (2015) Recovery of rare earths from weathered crust elutiondeposited rare earth ore without ammonia-nitrogen pollution: I. leaching with magnesium sulfate. Hydrometallurgy 153:58-65. https://doi.org/10.1016/j.hydromet.2015.02.011

Zhou YP, Bohor BF, Ren YL (2000) Trace element geochemistry of altered volcanic ash layers (tonsteins) in Late Permian coalbearing formations of eastern Yunnan and western Guizhou Province, China. Int J Coal Geol 44:305-324 